\title{
Blood Parameters of Lactating Cows Fed Calcium Salts as Energetic Source
}

\author{
William Del Conte Martins ${ }^{1,2}$, Sérgio Henrique Mioso Cunha', André Giarola Boscarato', \\ Jonathan Soares de Lima ${ }^{3}$, Jair Dario Esteves Junior ${ }^{3}$, Gian Luca Todero Uliana ${ }^{3}$, \\ Mateus Trindade Pedrini ${ }^{3}$ \& Luiz Romulo Alberton'
}

\begin{abstract}
Background: The negative energetic balance of lactating cows that occurs during the few weeks postpartum shifts the hormonal profile of the animal. These alterations may lead to metabolic disturbance as ketosis and lipid infiltration. Hypocalcemia is another metabolic problem that occurs in the peripartum period, it is characterized by the reduction in blood levels of calcium $\left(\mathrm{Ca}^{2+}\right)$ near birth. Blood parameters illustrates the nutritional status of milking cows. The serum levels of glucose, $\beta$-hydroxybutyrate (BHB) and cholesterol are parameters that reveal liver condition and it is very important for the metabolism of milking cows. The objective of this study was to evaluate three additives in the form of a calcium salts on blood parameters of lactating cows.

Materials, Methods \& Results: Two Latin square $4 \times 4$ were used, whereas one comprehended of early lactation cows and the other of mid lactation cows. Animals of 2 nd and 3rd parity were used only. Parity was distributed evenly among groups. The trial consisted of 4 groups with 4 treatments as follow: T1: $300 \mathrm{~g}$ of calcium acetate, T2: $200 \mathrm{~g}$ of calcium propionate, T3: $200 \mathrm{~g}$ of calcium salts of fatty acids, and T4: control without any calcium additive. Blood samples were collected for analysis of serial calcium, glucose, $\beta$-hydroxybutyrate (BHBA) and cholesterol. The calcium levels were higher in T1 than $\mathrm{T} 3$ in early lactation. There was no significant difference of glucose levels between groups. Groups T1 and T2 had lower amounts of BHBA. Cholesterol was higher in $\mathrm{T} 3$ and $\mathrm{T} 1$ in the early lactation and just in $\mathrm{T} 3$ was higher in the mid lactation. Discussion: Adjust the $\mathrm{Ca}^{2+}$ flow due to high feed consumption and milk production near birth is a big challenge for milking cows due to the difficulties to maintain normal serial levels of $\mathrm{Ca}^{2+}$ in the early lactation. The lower serial levels of $\mathrm{Ca}^{2+}$ in the group supplemented with calcium salts of fatty acids is due to its physical characteristics that reduces its effects on ruminal microbiota and also reduced absorption of fatty acids in intestine. The evaluation of total cholesterol can be a parameter to judge the productive capacity of milking cows, because it demonstrates the capacity of corporal fat mobilization and ingestion of energy to produce milk. An increase of total cholesterol in cows supplemented with calcium salts of fatty acids is justified by the higher intake of fatty acids in the feed containing fat, which leads to a greater lipid metabolism in blood. As the literature has limited information about calcium acetate, it is believed that the animals supplemented with calcium acetate showed higher levels of cholesterol because the acetate is converted to Acetyl coenzime A, it is the basis for cholesterol biosynthesis in lactating cows. The BHBA can be considered as an indicator of negative energetic balance due to its correlation between energetic demand and energy reserves. As propionate is produced by ruminal fermentation and is the principal source for gluconeogenesis in peripartum cows, it lowered level of BHBA in the propionate supplemented group. The acetate availability is fundamental to attend the energetic requirements of lactating cows. The acetate enters in the synthesis of fatty acids as Acetyl coenzyme-A or enters in Krebs cycle through condensation with oxaloacetate, this explains the lower serial levels of BHB in group T1. It was concluded that T1 and T2 lowered the values of BHBA in early lactation cows and the animals supplemented with calcium salts of fatty acids and calcium acetate shower higher levels of cholesterol in early lactation and the T3 group in the mid lactation.
\end{abstract}

Keywords: metabolism, propionate, glycogenic, calcium, lactation. 


\section{INTRODUCTION}

The negative energetic balance of lactating cows that occurs during the few weeks postpartum shifts the hormonal profile of the animal [22]. These alterations may lead to metabolic disturbance as ketosis, lipid infiltration [5] and hypocalcaemia [16]. The serial levels of glucose, $\beta$-hydroxybutyrate (BHBA) and cholesterol are parameters that reveals liver condition and it is very important for the metabolism of milking cows [22]. Serum level of $\mathrm{Ca}^{2+}$ in postpartum cows is very relevant in hypocalcemia prevention.

The purpose of lipid supplementation in diets of milking cows is to increase the energetic concentration of the diet and offer an energy subsidy for milk production, and the calcium salts of fatty acids (CSFA) can be an option [3]. Calcium propionate (CP) is also utilized as an energetic source. The propionate is produced out of ruminal and it the main precursor of glycogenesis in bovines [15]. In addition, to complement the fore mentioned findings, the calcium acetate (CA) was investigated as an innovative option for this study. Most body tissues use acetate as energy source hence it is converted to acetilcoenzyme-A within Krebs cycle [18], and the lack of information about the use of calcium acetate in milking cows indicate the need and the relevance of investigating it. The objective of this study is to evaluate the effects of energetic sources as calcium salts on metabolism of lactating dairy cows.

\section{MATERIALS AND METHODS}

\section{Animals and experimental design}

The study was carried out in Campus 2 of Universidade Paranaense, Umuarama, state of Paraná, Brazil. All procedures in this experiment were approved by the Ethical Committee of Universidade Paranaense. Eight Holstein cows, average body weight $540 \mathrm{~kg}+-30 \mathrm{~kg}$ and 5 years old were used. The animals were allocated in two latin square $(4 \times 4)$. One group had cows that were in their 7 th lactation day (early lactation). The other group had mid lactation cows $(\sim 110$ days). There were 4 treatments per group as follow: $\mathrm{T} 1=$ supplementation with $300 \mathrm{~g}$ of calcium acetate obtained from chemical reaction:

$\mathrm{Ca}(\mathrm{OH}) 2+2 .(\mathrm{CH} 3 \mathrm{COOH})=2$. $(\mathrm{CH} 3 \mathrm{COO}) \mathrm{Ca}+$ 2.H2O;

The pureness of calcium acetate were checked by the Chemistry Laboratory of Universidade
Paranaense. $\mathrm{T} 2=$ supplementation with $200 \mathrm{~g}$ of calcium propionate $\left(\text { Propimpex }^{\circledR}\right)^{1}$; T3= supplementation with $300 \mathrm{~g}$ of calcium salts of fatty acids salts $\left(\text { Megalac- } \mathrm{E}^{\circledR}\right)^{2}$; $\mathrm{T} 4=$ Control group without supplementation. Animals were housed in individual pens, the supplementation was added to the concentrated feed offered once a day after morning milking. Animals were milked twice a day at $7 \mathrm{am}$ and $5 \mathrm{pm}$. The amount of concentrate begun with $5 \mathrm{~kg}$ and were increased by $0.5 \mathrm{~kg} /$ day until reach the maximum of $8 \mathrm{~kg} / \mathrm{animal} /$ day and keep the proportion concentrate/bulky 40:60. Silage was given 3 times per day. Feed was weighted before serving and left over feed was calculated. Left over feed were sampled and subjected to bromatological analysis in the Laboratory of Bromatology of Escola Superior de Agricultura Luiz de Queiroz da Universidade de São Paulo. The diet was formulated based on NRC (2001) recommendations for a $540-\mathrm{kg}$ cow to produce $20 \mathrm{~kg} /$ day of milk containing $3.4 \%$ of milk fat and $3.2 \%$ protein. Ingredients and chemical composition of the basal diet are shown in Table 1.

The trial period was 21 days whereas the initial period comprehends of 14 days for adaptation and the remaining 7 days were the sampling period. Samples were collected in the $1 \mathrm{st}, 3 \mathrm{rd}$, 5th and 7 th day of the sampling period.

\section{Measurements and collection of samples}

Blood samples were collected via coccygeal vein into vacutainer tubes with either coagulation accelerator gel and centrifuged at $700 \mathrm{~g}$ for $10 \mathrm{~min}$. All samples were analyzed for glucose, total cholesterol and calcium in the Laboratory of Clinical Analysis of Universidade Paranaense using commercial kits for analysis. $\beta$-hydroxybutyrate (BHBA) was measure out of one drop of blood that was collected from the tip of the tail of each animal with commercial kit $\left(\text { Ketovet }^{\circledR}\right)^{3}$.

\section{Calculations and statistical analyses}

The results were obtained after statistical analysis with General Linear Models (GLM) of MiniTab 17® [25] with 5\% probability in reference to the following formula: $Y=\mu+\alpha+\beta+\gamma(\beta)+p+$ $\varepsilon$, where $\mu$ is the general mean, $\alpha$ is the fixed effect of treatment, $\beta$ is the random effect of square, $\gamma(\beta)$ is the random effect of animal within square, $p$ is the random effect of period and $\varepsilon$ is the random error. Comparisons between means were performed using Tukey test with $5 \%$ probability. 
Table 1. Ingredient and chemical composition of the basal diet (in $\mathrm{g} / \mathrm{kg}$ dry matter).

\begin{tabular}{ccccc}
\hline Nutrient & CG & CA & CP & CSFA \\
\hline Ingredients g kg- ${ }^{-1}$ & & & & 792.7 \\
Corn Silage & 800 & 792.7 & 795.2 & 117.6 \\
Corn grain & 117.6 & 117.6 & 117.6 & 70 \\
Soybean meal & 70 & 70 & 70 & 1 \\
Limestone & 1 & 1 & 1 & 1.4 \\
Sodium Clhoride & 1.4 & 1.4 & 1.4 & 10 \\
Minerals and Vitamins* & 10 & 10 & 10 & \\
Calcium Acetate & & 7.3 & & 7.3 \\
Calcium Propionate & & & 4.8 & 372 \\
CSFA & & & & 473 \\
Nutrient & 368 & 372 & 371 & 108.9 \\
Dry matter g kg ${ }^{-1}$ & 476 & 473 & 475 & 67.9 \\
Neutral detergente fiber & 109.5 & 108.9 & 108.9 & 30,7 \\
Crude Protein & 68.28 & 67.90 & 68.1 & 3,992 \\
Total digestible nutrients & 24.66 & 24.5 & 24.6 & 4000 \\
Ethereal extract & $3,995,2$ & 3,992 & & \\
NE (kcal g-1) & & & & \\
\hline
\end{tabular}

*Calcium 220 g/kg, Phosphorus 60 g/kg, Sulfur 20 g/kg, Magnesium 20g/kg, Potassium 35g/kg, Sodium 70 g/kg, Cobalt 15 mg/kg, Copper $700 \mathrm{mg} / \mathrm{kg}$, Chrome $10.00 \mathrm{mg} / \mathrm{kg}$, Iron $700 \mathrm{mg} / \mathrm{kg}$, Iodine $40 \mathrm{mg} / \mathrm{kg}$, Manganese 1,600 mg/kg, Selenium $19 \mathrm{mg} / \mathrm{kg}$, Zinc $2500 \mathrm{mg} / \mathrm{kg}$, Vitamin A 400,000 UI/kg, Vitamin D3 100,000 UI/kg, Vitamin E 2,400 UI/kg.

\section{RESULTS}

The $\mathrm{Ca}^{2+}$ values during the early lactation were higher in the CP supplemented group (9.35 mg / dL) than in the supplemented group with CSFA $(8.85 \mathrm{mg}$ / dL). There was no significant difference between the other groups. There was also no difference between the groups during the mid-lactation (Table 2).

No statistical difference was observed in the glucose levels between the groups during the early lactation and the mid-lactation, as can be observed in Table 2.
Animals supplemented with CA and CFA during the early lactation presented higher levels of total cholesterol $(P<0.05)$ than the other groups. There was also a statistical difference between $\mathrm{CG}$ and $\mathrm{CP}$, with higher levels for CG (Table 2). During the mid- lactation, there was only a statistical difference between the CFA group, which presented higher levels, and the CG and $\mathrm{CP}$ groups.

And serum levels of BHBA were lower for the $\mathrm{CA}$ and $\mathrm{CP}$ groups than the control group, as can be seen in Table 2.

Table 2. Blood parameters of lactating dairy cows feeding energetic sources in the calcium salts forms.

\begin{tabular}{|c|c|c|c|c|c|c|c|c|}
\hline & \multicolumn{4}{|c|}{ Early Lactation } & \multicolumn{4}{|c|}{ Mid-lactation } \\
\hline & $\mathrm{CA}$ & $\mathrm{CP}$ & CSFA & $\mathrm{CG}$ & $\mathrm{CA}$ & $\mathrm{CP}$ & CSFA & $\mathrm{CG}$ \\
\hline Calcium & $9.16^{\mathrm{ab}}$ & $9.35^{\mathrm{a}}$ & $8.85^{b}$ & $9.06^{\mathrm{ab}}$ & $9.49^{\mathrm{a}}$ & $9.29^{\mathrm{a}}$ & $9.21^{\mathrm{a}}$ & $9.12^{\mathrm{a}}$ \\
\hline Glucose & $52.18^{\mathrm{a}}$ & $52^{\mathrm{a}}$ & $54.06^{\mathrm{a}}$ & $55.37^{a}$ & $47.50^{\mathrm{a}}$ & $49.63^{\mathrm{a}}$ & $50.38^{a}$ & $48^{\mathrm{a}}$ \\
\hline Total Cholesterol & $111.12^{\mathrm{a}}$ & $85^{c}$ & $106.81^{\mathrm{a}}$ & $96.25^{\mathrm{b}}$ & $110^{\mathrm{ab}}$ & $99.69^{b}$ & $128.06^{\mathrm{a}}$ & $106.81^{b}$ \\
\hline BHBA & $0.79^{\mathrm{b}}$ & $0.78^{\mathrm{b}}$ & $0.94^{\mathrm{ab}}$ & $0.99^{\mathrm{a}}$ & & & & \\
\hline
\end{tabular}




\section{DISCUSSION}

Animals supplemented with calcium propionate had higher levels of $\mathrm{Ca}^{2+}(P<0.05)$ than the group supplemented with calcium salts of fatty acids. The supplementation of $\mathrm{Ca}^{2+}$ salts did not change the $\mathrm{Ca}^{2+}$ serial levels in mid lactation. The $\mathrm{Ca}^{2+}$ is essential for physiological processes and normal functioning of body tissues [9]. The animals in this study showed normal $\mathrm{Ca}^{2+}$ levels (between 8.5 and $10 \mathrm{mg} / \mathrm{dL}$ ), serial levels below $8 \mathrm{mg} / \mathrm{dL}$ of $\mathrm{Ca}^{2+}$ leads to subclinical hypocalcemia [8].

The clinical hypocalcemia or milk fever is an acute metabolic problem that occurs in 5 to $6 \%$ of milking herds, the subclinical hypocalcemia may happen in up to $50 \%$ animals within a herd. Animals with such a problem are predisposed to abomasum displacement, dystocia, ketosis, uterus prolapse and retained placenta [23].

Adjust the $\mathrm{Ca}^{2+}$ flow due to high feed consumption and milk production near birth is a big challenge for milking cows due to the difficulties to maintain normal serial levels of $\mathrm{Ca}^{2+}$ in the early lactation [17]. Stabilization of serum levels of $\mathrm{Ca}^{2+}$ and preventing hypocalcemia was accomplished by supplementation with calcium propionate $[7,11]$. Some articles confirmed the increase of $\mathrm{Ca}^{2+}$ serial levels [20], while other did not observe any changes in serum level [7]. Although these articles investigated the supplementation during birth or 12 and $24 \mathrm{~h}$ postpartum, the current study evaluate the daily supplementation after 7 days of lactation, hence the control mechanisms of $\mathrm{Ca}^{2+}$ serial levels are already active, and this explains the non-significant difference of $\mathrm{Ca}^{2+}$ serial levels when compared with control group. The lower serial levels of $\mathrm{Ca}^{2+}$ in the group supplemented with calcium salts of fatty acids is due to its physical characteristics that reduces its effects on ruminal microbiota and also reduced absorption of fatty acids in intestine [27]. The supplementation with calcium salts offers supply of $\mathrm{Ca}^{2+}$ and energy because propionate and acetate are sources of energy for ruminants. By that, animals supplemented with calcium propionate and calcium acetate are able to keep adequate serial levels of $\mathrm{Ca}^{2+}$ postpartum and energy supply for the negative energetic balance that occurs in this period.

In this study were not observed differences in serum levels of glucose (Table 2). The availability of glucose for mammary gland has a direct impact on milk production, because lactose is the main osmoregulator substance in the water absorption by mammary gland. The increase of milk production is due to changes in the glucose availability for mammary gland [12]. This hypothesis is supported by the results obtained by these authors group [1], whereas glycemia had negative correlation $(\mathrm{r}=-0,39 ; P<0.01)$ with milk solids not fat, and despite of non-significance with milk production $(\mathrm{r}=-0.17)$ even among animals with normal glycemic levels. Similar results were also reported by other authors in animals supplemented with calcium salts of fatty acids [14] and in animals supplemented with calcium propionate [11].

Total Cholesterol levels were significantly higher $(P<0.05)$ [Table 2] in animals supplemented with calcium salts of fatty acids and calcium acetate in early lactation when compared with calcium propionate and the control group. In mid lactation, the group supplemented with calcium salts of fatty acids had higher the serial levels of total cholesterol $(P<$ $0.05)$ than the control and the calcium propionate group. Besides participating in the formation of cellular membranes, the cholesterol is precursor of steroidal hormones synthesis, vitamin D, and biliary salts. It is also part of lipoproteins that are synthetized in the liver and intestine, and act in the transport of lipids in the body [2]. The evaluation of total cholesterol can be a parameter to judge the productive capacity of milking cows, because it demonstrates the capacity of corporal fat mobilization and ingestion of energy to produce milk [10]. The significant increase of cholesterol also improves reproductive performance, because it is precursor of steroidal hormones such a progesterone [26]. An increase of total cholesterol in cows supplemented with calcium salts of fatty acids was reported [3]. It justified by the higher intake of fatty acids in the feed containing fat that leads to a greater lipid metabolism in blood.

As the literature has limited information about calcium acetate, it is believed that the animals supplemented with calcium acetate showed higher levels of cholesterol than the control group and propionate fed group because the acetate is converted to Acetyl coenzime A [18], it is the basis for cholesterol biosynthesis in lactating cows [2]. The group supplemented with calcium propionate had lower levels of cholesterol than all groups, it was considered due to the higher milk production (data not published). Cholesterol 
levels may vary according to animal age and milk productivity [21].

Cows fed calcium acetate and calcium propionate had lower serial levels $(P<0.05)$ of BHBA than control group (Table 2). In the post-partum period, the increase of lipid mobilization boosts the presence of non-esterified fatty acids in blood and consequently it can be totally oxidized to $\mathrm{CO}_{2}$ in the liver or partially oxidized to ketonic bodies as BHBA [12]. The BHBA can be considered as an indicator of negative energetic balance due to its correlation between energetic demand and energy reserves [19]. Clinical and sub clinical ketosis are consequences of a negative energetic balance, the subclinical ketosis without clinical signs was defined as hyperketonemia [6]. Suthar et al. [28] named subclinical ketosis when cows showed higher serial levels of BHB than $1.0 \mathrm{mmol} / \mathrm{L}$. It was reported the increase in the risk of development of clinical ketosis and metritis in cows with more than $1.0 \mathrm{mmol} / \mathrm{L} \mathrm{BHB}$ level after the 3rd up to 14 th day after birth [19]. The results of this study match the findings of other authors that supplementation of calcium propionate showed lower serial level of BHB than control group $[12,13]$. The same results reported in female buffalo [4]. As propionate is produced by ruminal fermentation and is the principal source for gluconeogenesis in peri partum cows, it lowered level of BHBA in the propionate-supplemented group [24]. Propionate stimulates insulin secretion, and it suppress the non-steroidal fatty acids [11], moreover, it leads to a lowered transport of fatty acid to mitochondria [13].

The acetate availability is fundamental to attend the energetic requirements of lactating cows
[29]. The acetate enters in the synthesis of fatty acids as Acetyl coenzyme-A or enters in Krebs cycle through condensation with oxaloacetate [30], this explains the lower serial levels of BHB in-group $\mathrm{T} 1$. These findings are very important because the supplemented acetate is promptly absorbed and immediately increase its availability to the animals, thus supplying the energetic demand of the animal. The results demonstrate that the calcium acetate and calcium propionate supplementation reduces body fat mobilization and reduce the negative energetic balance in early lactating cows.

\section{CONCLUSIONS}

The ingestion of fatty acids calcium salts increased cholesterol levels of lactating cows. Animals supplemented with calcium acetate and calcium propionate had lower serial levels of BHB, lowered the body fat mobilization that consequently prevent Ketosis, thus it demonstrates the efficiency of these additives in energetic supplementation. More studies are needed in order to obtain more insights about these additives.

\section{MANUFACTURERS}

${ }^{1}$ Impextraco Latin America Com. e Ind. de Produtos para Nutrição Ltda. Curitiba, PR, Brazil.

${ }^{2}$ Elanco Saúde Animal Ltda. São Paulo, SP, Brazil.

${ }^{3}$ KetoVet. Nova Lima, MG, Brazil.

Acknowledgements. We thank the Universidade Paranaense for granting the animals and the necessary structure for research and CAPES by scholarship.

Declaration of interest. The authors report no conflicts of interest. The authors alone are responsible for the content and writing of the paper.

\section{REFERENCES}

1 Alberton L.R., Fanin M., Oro M., Savanhago R. \& Martins W.D.C. 2013. Efeito da suplementação de vacas com propionato de cálcio na dieta sobre a glicemia, produção e composição do leite. Enciclopédia Biosfera. 17: 1202-1212.

2 Bruss M.L. 2008. Lipids and Ketones. In: Kaneko J.J., Harvey J.W. \& Bruss M.L. (Eds). Clinical Biochemistry of Domestic Animals. 6th edn. San Diego: Elsevier, pp.81-115.

3 Freitas-Júnior J.E., Rennó F.P., Silva L.F.P., Gandra J.R., Maturana-Filho M., Foditsch C. \& Venturelli B.C. 2010. Parâmetros sanguíneos de vacas leiteiras suplementadas com diferentes fontes de gordura. Ciência Rural. 40(4): 950-956.

4 Gabr A.E.A.A., Ebrahim S.A., El-Hawary A.F.A., Fathala M.M., El-Gohary E.S.H., Ahmed S.E.M. \& AbdelLatif M.A. 2017. Upgrading Milk Productivity of Primiparous Buffaloes Using Glycogenic Precursors; Implications on Milk Production and Blood Biochemical Parameters. Zagazig Veterinary Journal. 45(2): 92-103.

5 Garcia A.M.B., Cardoso F.C., Campos R., Thedy D.X. \& Gonzales F.H.D. 2011. Metabolic evaluation of dairy cows submitted to three different strategies to decrease the effects of negative energy balance in early postpartum. Pesquisa Veterinária Brasileira. 31(Suppl 1): 11-17. 
6 Geishauser T., Leslie K., Tenhag J. \& Bashiri A. 2000. Evaluation of eight cow-side ketone tests in milk for detection of subclinical ketosis in dairy cows. Journal of Dairy Science. 83(2): 296-299.

7 Goff J.P., Horst R.L., Jardon P.W., Borelli C. \& Wedam J. 1996. Field trials of an oral calcium propionate paste as an aid to prevent milk fever in periparturient dairy cows. Journal of Dairy Science. 79(3): 378-383.

8 Goff J.P., Liesegang A. \& Horst R.L. 2014. Diet induced pseudohypoparathyroidism: a hypocalcemia and milk fever risk factor. Journal of Dairy Science. 97(3): 1520-1528.

9 Horst R.L., Goff J.P. \& Reinhardt T.A. 1994. Calcium and Vitamin D metabolism in dairy cow. Journal of Dairy Science. 77(7): 1936-1951.

10 Ingraham R.H. \& Kappel L.C. 1998. Metabolic profile testing. Veterinary Clinics of North America: Food Animal Practice. 4(2): 391-411.

11 Kara Ç., Orman A., Udum D., Yavuz H.M. \& Kovanlikaya A. 2009. Effects of calcium propionate by different numbers of applications in first week postpartum of dairy cows on hypocalcemia, milk production and reproductive disorders. Italian Journal of Animal Science. 8(2): 259-270.

12 Lemosquet S., Raggio G., Lobley G.E., Rulquin H., Guinard-Flament J. \& Lapierre H. 2009. Whole-body glucose metabolism and mammary energetic nutrient metabolism in lactating dairy cows receiving digestive infusions of casein and propionic acid. Journal of Dairy Science. 92(12): 6068-6082.

13 Liu Q., Wang C., Yang W.Z., Guo G., Yang X.M., He D.C., Dong K.H. \& Huang Y.X. 2010. Effects of calcium propionate supplementation on lactation performance, energy balance and blood metabolites in early lactation dairy cows. Journal of Animal Physiology and Animal Nutrition. 94(5): 605-614.

14 Lohrenz A.K., Duske K., Scheneider F., Nürnberg K., Losand B., Seyfert H.M., Metges C.C. \& Hammon H.M. 2010. Milk performance and glucose metabolism in dairy cows fed rumen-protected fat during mid lactation. Journal of Dairy Science. 93(12): 5867-5876.

15 McCarthy M.M., Piepenbrink M.S. \& Overton T.R. 2015. Associations between hepatic metabolism of propionate and palmitate in liver slices from transition dairy cows. Journal of Dairy Science. 98(10): 7015-7024.

16 Neves R.C., Leno B.M., Stokol T., Overton T.R. \& McArt J.A.A. 2017. Risk factors associated with postpartum subclinical hypocalcemia in dairy cows. Journal of Dairy Science. 100(5): 3796-3804.

17 Oetzel G.R. 2013. Oral calcium supplementation in peripartum dairy cows. The Veterinary Clinics of North America: Food animal practice. 29(2): 447-455.

18 Osorio J.H. \& Vinazco J. 2010. El metabolismo lipídico bovino y su relación com la dieta, condicion corporal, estado productivo y patologias asociadas. Biosalud. 9(2): 52-56.

19 Ospina P.A., Nydam D.V., Stokol T. \& Overton T.R. 2010. Associations of elevated nonesterified fatty acids and $\beta$-hydroxybutyrate concentrations with early lactation reproductive performance and milk production in transition dairy cattle in the northeastern United States. Journal of Dairy Science. 93(4): 1596-1603.

20 Peralta O.A., Monardes D., Duchens M., Moraga L. \& Nebel R.L. 2011. Supplementing transition cows with calcium propionate-propylene glycol drenching or organic trace minerals: implications on reproductive and lactation performances. Archivos de Medicina Veterinaria. 43(1): 65-71.

21 Pogliani F.B. \& Birgel-Júnior E. 2007. Valores de referência do lipidograma de vacas holandesas criadas no Estado de São Paulo. Brazilian Journal of Veterinary Research and Animal Science. 44(5): 373-383.

22 Puppel K. \& Kuczynska B. 2016. Metabolic profiles of cow's blood; a review. Journal of the Science of Food and Agriculture. 96: 4321-4328.

23 Reinhardt T.A., Lipollis J.D., McCluskey B.J., Goff J.P. \& Horst R.L. 2011. Prevalence of subclinical hypocalcemia in dairy herds. The Veterinary Journal. 188(1): 122-124.

24 Reynolds C.K., Aikman P.C., Lupoli B., Humphries D.J. \& Beever D.E. 2003. Splanchnic metabolism of dairy cows during the transition from late gestation through early lactation. Journal of Dairy Science. 86(4): 1201-1217.

25 Ryan B.F. \& Joiner B.L. 1994. Minitab handbook. 3rd edn. Belmont: Duxbury Press, 448p.

26 Silveira M.F., Restle J., Menezes L.F.G., Brondani I.L., Nörnberg A.M., Callegaro A.M. 2012. Metabólitos sanguíneos de vacas de corte suplementadas ou não com sais de cálcio de ácidos graxos durante o período pré e/ou pós-parto. Arquivo Brasileiro de Medicina Veterinária e Zootecnia. 64(6): 1418-1426.

27 Smith W.A. 1991. Fats for lactating dairy cows. South African Journal of Animal Science. 21(1): 1-10. 
28 Suthar V.S., Canelas-Raposo J., Deniz A. \& Heuwieser W. 2013. Prevalence of subclinical ketosis and relationships with postpartum diseases in European dairy cows. Journal of Dairy Science. 96(5): 2925-2938.

29 Urrutia N.L. \& Harvatine K.J. 2017. Acetate Dose-Dependently Stimulates Milk Fat Synthesis in Lactating Dairy Cows. The Journal of Nutrition. 147(5): 763-769.

30 Van Soest P.J. 1994. Nutritional ecology of the ruminant. 2nd edn. New York: Cornell University Press, $476 \mathrm{p}$. 